\title{
THOMAS JEFFERSON'S UNIVERSITY OF VIRGINIA AND THE PARIS HOSPITALS ON THE EVE OF THE FRENCH REVOLUTION
}

\author{
by
}

\author{
LOUIS S. GREENBAUM *
}

Thomas Jefferson's five years in Paris as American ambassador (1784-1789) saw a period of dynamic urban growth, public health reform ${ }^{1}$ and massive building projects, both public and private in the French capital-churches, hospitals, monumental toll houses, schools, theatres, public squares, bridges, markets and hotels particuliers. ${ }^{2}$ Jefferson acknowledged as much in a letter of 14 August 1787:

I will observe to you that wonderful improvements are making here in various lines. In architecture the wall of circumvallation round Paris and the palaces by which we are to be let in and out are nearly compleated [sic], 4 hospitals are to be built instead of the old Hôtel-Dieu, one of the old bridges has all it's [sic] houses demolished and a second nearly so, a new bridge is begun at the Place Louis XV. ${ }^{3}$

By his reference to the Hôtel-Dieu, Jefferson was alluding to a project which had won the widespread enthusiasm and financial support of Parisians-the relocation of the ancient municipal hospital from its place in the shadow of Notre Dame Cathedral, where it operated for 1100 years, and the construction of four new hospitals in less populous outlying sections of the city.

\footnotetext{
* Professor Louis S. Greenbaum, Department of History, University of Massachusetts at Amherst, Herter Hall, Amherst, MA 01003, USA.

Variations of this paper were presented at the American Society for Eighteenth-Century Studies Twentieth Annual Meeting (New Orleans), 31 March 1989 and the Society for French Historical Studies Thirty-Seventh Annual Conference (Vancouver) 22 March 1991.

Abbreviation: The papers of Thomas Jefferson, ed. J. P. Boyd, 24 vols, Princeton University Press, 1950-1990, has been shortened throughout to Papers $T J$.

${ }^{1}$ Handily summarized by the surgeon and hospital-reformer, Jacques Tenon (1724-1816): “Never under any reign, was there more effort to pierce new streets, to remove old houses from bridges, to build quays, to extend and multiply the number of public markets, to remove cemeteries, to transfer butcheries and slaughterhouses from the central city, in one word to get the air to circulate, to dry out the soil, to guarantee against dangerous effects of accumulated putrid materials. All these precautions more and more favour the health of the city, and they are so many debts we owe to the benevolence of Louis XVI and to the zeal of his Minister of the Department of Paris." Mémoires sur les hopitaux de Paris, Paris, 1788, p. 401.

${ }^{2}$ H. Rosenau, Social purpose in architecture: Paris and London compared, 1760-1800, London, Studio Vista, 1970, pp. 10-16, 26-48; A. Braham, The architecture of the French Enlightenment, Berkeley, University of California Press, 1980, pp. 210-50; H. C. Rice, Jr., Thomas Jefferson's Paris, Princeton University Press, 1976, pp. 3-13.

${ }^{3}$ To David Humphreys, Papers TJ, vol. 12, p. 32.
} 


\section{Thomas Jefferson's University of Virginia and the Paris Hospitals}

Public interest in hospitals had been sparked by the Paris Academy of Sciences which, in December 1785, had appointed an eminent committee under the chairmanship of the astronomer and future mayor of Revolutionary Paris, JeanSylvain Bailly, to investigate the Hôtel-Dieu. ${ }^{4}$ The committee worked for nearly three years under the sponsorship of Louis-Auguste Le Tonnelier, the Baron de Breteuil, powerful minister of the King's Household and the Department of Paris, and published three reports ${ }^{5}$ given much publicity by the government, which thrust hospitals and health-care, as never before, into the limelight of public scrutiny. The Academy gave scientific validation to long-standing prejudices against the Hôtel-Dieu, popularly conceived as a death-trap because of its unhealthy location in the densely populated centre, and its crowded mass of 3,000 patients ( 84 per cent of the cities and towns of France had fewer inhabitants) ${ }^{6}$ lying four to six in a bed, its mixing diseases in the same wards and even the same beds, its vitiated air, deficient water, disregard of safety, and the danger it posed as a fire-hazard, polluter of the water supply and source of contagion.

The committee's point of departure was to disencumber the hospital from its traditional association as a refuge of Christian charity, indigence and confinement. Viewed rather as a "factory" or "healing machine"7 for patient-citizens, the hospital

\footnotetext{
${ }^{4}$ L. S. Greenbaum, 'Jean-Sylvain Bailly, the Baron de Breteuil and the "Four new hospitals" of Paris', Clio Medica, 1973, 8: 261-84 and 'Scientists and politicians: hospital reform in Paris on the eve of the French Revolution', The consortium on revolutionary Europe, 1750-1850, Proceedings 1973, Gainesville, 1975, pp. 168-91.

${ }^{5}$ Extrait des registres de l'Académie royale des Sciences du 22 novembre 1786. Rapport des Commissaires chargés, par l'Académie, de l'examen du projet d'un nouvel Hôtel-Dieu, Paris, 1786, 128 pp.; Extrait des registres de l'Académie royale des Sciences du 20 juin 1787. Rapport des commissaires chargés, par l'Académie, des projets relatifs à l'établissement des quatre hôpitaux, Paris, 1787, 15 pp.; Extrait des registres de l'Académie royal des Sciences du 12 mars 1788. Troisième rapport des commissaires chargés, par l'Académie, des projets relatifs à l'établissement des quatre hôpitaux, Paris, 1788, 36 pp.

${ }^{6}$ A. Soboul, La France à la veille de la Révolution. Economie et société, Paris, Société d'Édition d'Enseignement Supérieur, 1974, p. 65.

${ }^{7} \mathrm{~J}$. Tenon, Bibliothèque Nationale (Paris), Manuscrits, Nouvelles Acquisitions françaises 11357, fol. 19. Cf. L. S. Greenbaum, “Measure of Civilization": the hospital thought of Jacques Tenon on the eve of the French Revolution', Bull. Hist. Med., 1975, 90: 46; J.-B. LeRoy, 'Précis d'un ouvrage sur les hôpitaux, dans lequel on expose les principes résultant des observations de physique et de médecine qu'on doit avoir en vue dans la construction de ces édifices, avec un projet d'hôpital disposé d'après ces principes', Mémoires de l'Académie royale des Sciences, 1787, Paris, 1789, pp. 585-600. Cf. L. S. Greenbaum, 'Tempest in the Academy: Jean-Baptiste Le Roy, the Paris Academy of Sciences and project of a new Hôtel-Dieu,' Arch. int. Hist. Sci., 1974, 24: 122-40. The pre-Revolutionary French hospital has attracted a multitude of significant studies: M. Foucault, The birth of the clinic: an archaeology of medical perception, transl. A. M. Sheridan Smith, New York, Pantheon, 1973; M. Foucault et al., Les machines à guérir: aux origines de l'hopital moderne, Paris, Dossiers et documents d'architecture. Institut de l'environnement, 1976; C. C. Gillispie, Science and polity in France at the end of the Old Regime, Princeton University Press, 1980, esp. pp. 250-6; H. Mitchell, 'Politics in the service of knowledge: the debate over the administration of medicine and welfare in the late 18th century France,' Soc. Hist., 1981, 6: pp. 185-207; J.-P. Goubert, 'La médicalisation de la société française, 1770-1830', Historical reflexions, (Waterloo, Canada) 1982, vol. 9; C. Jones, Charity and "Bienfaisance": the treatment of the poor in the Montpellier region, 1740-1815, Cambridge University Press, 1982, and his The charitable imperative. Hospitals and nursing in Ancien Regime and Revolutionary France, London and New York, Routledge, 1989; T. M. Adams, Bureaucrats and beggars. French social policy in the Age of the Enlightenment, Oxford University Press, 1990, pp. 124-8; 146-7. For the hospital within a wider context of institutional discipline and surveillance, cf. M. Foucault, Discipline and punish. The birth of the prison, transl. A. M. Sheridan Smith, New York, Random House,
} 


\section{Louis S. Greenbaum}

and its location, design, construction, organization and operation could no longer be left, as in the past, to accident, convention or expedience. With a death rate of 25 per cent, purportedly the highest of any hospital in Europe, the Paris Hôtel-Dieu not only deprived the state of thousands of productive citizens each year but retarded population growth and reduced the nation's workforce upon which depended its strength and wealth.

The committee rejected traditional large block structures of the Baroque like the Hôtel-Dieu, Bicêtre and La Salpêtrière, which were either designed a century before by architects oblivious to health factors, or were structures converted from ecclesiastical or other usages and therefore unsuited to the care of the sick. In reaction, the scientists advocated a new kind of hospital design, a pavilion or isolated ward where patients would be separated by disease and housed in single beds. The new hospital was to be a place where innovations in physics, chemistry, pathological anatomy, surgery, medical technology, sanitation, architecture and hospital administration would be practised. The hospital commission applauded the pavilion concept in Louis XIV's château of Marly $^{8}$ and found its ideal model in the British naval hospital at Plymouth, built in 1764 and visited by two of its members in $1787 .{ }^{9}$ The pavilion would become the regnant model for hospitals built all over Europe and America during the course of the next century. ${ }^{10}$

On 22 June 1787, Louis XVI ordered the building of four new hospitals of 1200 beds each, in 12 symmetrical parallel pavilions along a main axis, six on either side of an open garden, with a central chapel building at its head and connected by covered walkways for convalescing patients. ${ }^{11}$ The new design promised superior ventilation, economy and efficiency, as well as cleanliness, privacy and safety while cutting down the risk of fire and contagion, and reducing noise. ${ }^{12}$

Responding to the Academy's public appeal for the best form of hospitals and health-delivery for the capital, one of Thomas Jefferson's closest French friends, the Marquis de Condorcet, permanent secretary of the Academy of Sciences, submitted a paper on hospital-planning to his Academy colleagues. Seeking to nationalize and laicize medical care, Condorcet proposed a network of local, democratically organized health-centres, thereby transferring the main burden of medical care from

1977, pp. 184-92. And for a survey of medical personnel within the hospitals, cf. T. Gelfand, Professionalizing modern medicine: Paris surgeons and medical science and institutions in the 18th century, Westport, Conn., and London, Greenwood Press, 1980.

${ }^{8}$ Tenon, op. cit., note 1 above, p. vii; Greenbaum, op. cit., note 7 above, p. 126.

9 Tenon and the physicist Charles-Augustin Coulomb. In a letter to Tenon, Chairman Bailly acknowledged that the Plymouth hospital was the model hospital of all Europe, more than amply justifying the committee's recommendations "... . most useful to find our great plan already executed ... an experiment already accomplished”. B. N. Manuscripts, Nouvelles Acquisitions françaises, 11357, fol. 3; Extrait des registres de l'Académie royale des Sciences du 12 mars 1788 , see note 5 above, p. 30; Tenon, op. cit., note 5 above, pp. liii-liv; cf. L. S. Greenbaum, "The Commercial Treaty of Humanity": La tournée des hôpitaux anglais par Jacques Tenon en 1787', Rev. Hist. Sci., 1971, 24: 341

${ }^{0} \mathrm{~J}$. D. Thompson and G. Goldin, The hospital: a social and architectural history, New Haven and London, Yale University Press, 1975, pp. 170-205.

11 Troisième Rapport des commissaires, reproduced in Rosenau, op. cit., note 2 above, pp. 55-7.

12 Extrait des registres de l'Académie royale des Sciences du 22 novembre 1786, see note 5 above, pp. 109-15; Tenon, op. cit., note 8 above, pp. 419-24. 


\section{Thomas Jefferson's University of Virginia and the Paris Hospitals}

the hospital-long associated with indigence and Christian charity. ${ }^{13}$ Another respondent to the Academy was the physiocrat, physician and biographer of Turgot, Pierre-Samuel Du Pont de Nemours. Du Pont and Jefferson became acquainted in 1786 and formed a friendship which lasted nearly thirty years. Their ideas on agriculture, economics, and education reveal striking agreement. ${ }^{14}$ So, too, their views on social welfare and the treatment of the sick poor.

Du Pont's paper, Ideas on the nature, form and extent of assistance to give the sick poor in a large city, was written and published at the behest of the Academy committee. ${ }^{15}$ In it the physiocrat urged that the ancient Hôtel-Dieu be closed down, and that it be replaced by a more effective health programme for the city of Paris not through hospitals but rather through a combination of home-care for families and those with a fixed abode, and a series of neighbourhood hospices and nursing homes for the homeless. Du Pont's paper must be located in the context of numerous French writers who were troubled by the ancient association of the hospital with indigence and confessional charity. While physiocrats like the elder Mirabeau and Quesnay and populationists like Montyon argued persuasively for a numerous and healthy population in the interests of a rich and powerful state,${ }^{16}$ philosophes like Voltaire and Diderot were forceful in their condemnation of the hospital as a retrograde institution, unknown to Antiquity and an obstacle to the attainment of a rational, enlightened society. ${ }^{17}$ Hospitals were alleged to foster laziness and vice, to afford an easy berth for loafers who, instead of cultivating the land, engendered misery and depopulation and robbed labour of honour and respectability. The hospital was blamed as a source of national impoverishment, since its many sturdy inmates who feigned illness escaped the obligation of gainful employment, threw their dependants into pauperism and diminished productivity, thereby adding to the burden of relief. To thoughtful critics like Montesquieu and Rousseau, the solution to poverty lay not

${ }^{13}$ L. S. Greenbaum, 'Condorcet's "Mémoire sur les hôpitaux" (1786): an English translation and commentary', Condorcet studies, eds L. C. Rosenfield and R. H. Popkin, vol 1, Atlantic Highlands, P. Lang, 1984, pp. 83-97. Both Condorcet and Du Pont were prominent members of the américaniste circle of Turgot who saw America rather than Britain as the model of political reform in France. Both were linked in friendship to Franklin and Jefferson. See J. Appleby, 'America as a model of radical French reformers of 1789', William and Mary Quarterly, 3rd ser., 1971, 28: p. 274.

14 Thomas Jefferson and Pierre-Samuel Du Pont de Nemours, 1798-1817, ed. D. Malone, Boston and New York, Houghton Mifflin, 1930; The correspondence of Jefferson and Du Pont de Nemours, ed. G. Chinard, Baltimore, Chartres, 1931.

${ }^{15}$ Paris, Moutard, 1786, 64 pp. Principally through Du Pont's friend, Lavoisier, Cf. L. S. Greenbaum, 'Health-care and hospital-building in eighteenth-century France: reform proposals of Du Pont de Nemours and Condorcet', Stud. Voltaire 18th Century, 1976, 52: 906. Du Pont's paper was in Jefferson's library, cf. E. M. Sowerby, Catalogue of the library of Thomas Jefferson, Washington, 1952, vol. 3, No. 2386 , p. 34. For the background of Du Pont's treatise in his economic thought cf. J. J. McLain, The economic writings of Du Pont de Nemours, Newark, University of Delaware Press, 1977, pp. 140-1.

${ }^{16}$ V. de Riquetti, Marquis de Mirabeau, L'ami des hommes ou traité de la population, Avignon, 1756-1758, 2 vols. esp. part iv, pp. 20-8; F. Quesnay, Encyclopédie articles 'fermiers' (1756), 'grains' and 'hommes' (1757) in François Quesnay et la physiocratie, Paris, Institut National d'Études Démographiques, 1958, vol. 2, 427-578; Moheau (pseud. for Montyon), Recherches et considérations sur la population de la France (1788), ed. R. Gonnard, Paris, Geuthner, 1912, pp. 199-218.

${ }_{17}$ Voltaire, Dictionaire philosophique, article 'charité', Oeuvres complètes de Voltaire, Kehl edn., n.p., 1785, vol. 49, 239-47; Diderot, Encyclopédie, article 'hôpital, vol. 8, Paris, 1765, pp. 293-4. 


\section{Louis S. Greenbaum}

in more hospitals and charities, but rather in bridging the enormous gap between rich and poor and in instituting greater employment opportunity. ${ }^{18}$

$\mathrm{Du}$ Pont held that man through his own toil must be responsible for his needs in health as well as in sickness. When this was not possible he should then have recourse to family and neighbours to regain self-sufficiency. The dehospitalization of disease and poverty by medical assistance at home, Du Pont asserted, was more humane, healthier and cheaper than the hospital and promised greater therapeutic success free from cross-infection. It restored familial and social relationships in the natural domestic environment. Domicilary care facilitated the patients' return to work, thereby discouraging beggary, and involved the local citizenry in the responsibility of aiding their neighbours as practised in England and Holland.

Whereas the natural setting of the family, man and disease was the home, whose rehabilitative function would restore health and the resumption of familial and social obligations, the hospital was an artificial and unnatural assembly of diseases and death. While the home recreated human and material resources the hospital destroyed the healing function and life itself. Treatment by family, the fundamental moral unit, whose care is a function of love and duty, is spontaneous and motivated by the desire to cure. Removal to the hospital implied a double liability. On the one hand it deprived the sick of a better chance of recovery through the therapeutic ministrations of family and neighbours. On the other, the vastly greater mortality of the Hôtel-Dieu threatened permanent loss of income and the viability of the family itself.

On 5 November 1787, Du Pont sent Jefferson a copy of his paper and wrote, "I congratulate myself for having affirmed several principles which I found in your Notes on Virginia". ${ }^{19}$ In chapter XIV of the Notes Jefferson had described the provision of poor relief and health-care in Virginia and expressed an aversion for hospitals which linked him closely to Du Pont and other liberal reformers of the French Enlightenment. He described the parish relief system of his state as the most effective, inexpensive and compassionate scheme of self-help and home-care. Parish assistance and household relief by friends and neighbours, Jefferson asserted

is without comparison better than in a general hospital, where the sick, the dying and the dead are crammed together, in the same rooms, and often in the same beds. The disadvantages, inseparable from general hospitals, are such as can never be counterpoised by all the regularities of medicine and regimen. Nature and kind nursing save a much greater proportion in our plain way, at a smaller expense, and with less abuse. ${ }^{20}$

\footnotetext{
${ }^{18}$ Montesquieu, De l'esprit des lois, Paris, Edn. Pléiade, 1951, p. 712; Rosseau, Encyclopédie article 'De l'economie politique', in The political writings of J.-J. Rosseau, ed. C. E. Vaughan, New York, Wiley, 1960 , vol. 1, pp. 254-5. For alternative public policies governing the poor-confinement, prison, hospital and family aid, cf. M. Foucault, Madness and civilization. A history of insanity in the Age of Reason, transl. R. Howard, New York, Random House, 1973, pp. 221-40.

${ }_{19}$ Papers TJ, vol. 12, p. 326. On the French background of Jefferson's Notes on the State of Virginia, cf. D. Medlin, 'Thomas Jefferson, André Morellet and the French version of the Notes on the State of Virginia', William and Mary Quarterly, 1978, 35: pp. 85-99.

${ }^{20}$ Thomas Jefferson's 'Notes on the State of Virginia', ed. W. Peden, Chapel Hill, University of North Carolina Press, 1955, pp. 133-4. In Virginia material relief to needy sick in their homes or with neighbours pretty consistently followed similar practices in the other colonies. Cf. A. Deutsch, 'Sick and poor colonial times', Am. hist. Rev., 1941, 46: 560-79; D. J. Rothman, The discovery of the asylum: social order and disorder in the new Republic, Boston, Little Brown \& Co., 1971, pp. 32-5.
} 


\section{Thomas Jefferson's University of Virginia and the Paris Hospitals}

Just as Du Pont believed that there would be no need for hospitals if there were no poor, ${ }^{21}$ so Jefferson hoped that urban institutions like hospitals would not be needed in America, since the population they were meant to serve would not exist in a rural, agricultural and self-sufficient society. Jefferson gave much thought as to how great disparities of wealth might be avoided in the new nation so that Americans could be assured of prosperity, freedom, happiness, independence and moral virtue, so long as plentiful land, and with it the promise of a rising standard of living, would continue to be made available to citizens. ${ }^{22}$

Two parallel lines of thinking, converging in the reformist climate of preRevolutionary Paris, afford an interesting illustration of the thesis that the Enlightenment, while conceived in Europe, was being realized in America. ${ }^{23}$ French reformers, constantly dogged by privilege, bureaucratic obstruction and institutional opposition, could note with satisfaction that their reformist ideas were being practised in the United States. ${ }^{24}$ Confirming this, Jefferson wrote to Du Pont on 6 November that "... America furnished proof of the soundness of your theory". 25 Until the end of his life Jefferson never changed his unfavourable attitude to hospitals, which he considered instruments of human degradation and indignity. ${ }^{26}$

It is certain that Jefferson shared with Parisians the excitement of plans to rebuild the Hôtel-Dieu and to create new hospitals for the city of Paris, one of the most popular events in the capital during his stay. ${ }^{27}$ At least five letters over a period of seven months mentioned the planned reform. ${ }^{28}$ Not only was he aware of the pavilion system proposed by the Academy commission, but he was friendly with two of its prominent members, the celebrated chemist Lavoisier and the naturalist Daubenton, close

${ }^{21}$ Greenbaum, op. cit., note 15 above, p. 910.

22 Papers TJ, vol. 8, pp. 681-3; cf. J. Appleby, 'What is still American in the political philosophy of Thomas Jefferson', William and Mary Quarterly, 1982, 39: 295-6; D. R. McCoy, The elusive republic: political economy in Jeffersonian America, New York, Norton, 1982, pp. 13-17.

${ }^{23}$ H. S. Commager, The empire of reason. How Europe imagined and America realized the Enlightenment, New York, Doubleday, 1978. For an older treatment, cf. D. Echeverria, Mirage in the West. A history of the French image of American society to 1815, Princeton University Press, 1957.

${ }^{24}$ Papers TJ, vol. 12, p. 326, cf. Appleby, op. cit., note 22 above, p. 291. Durand Echeverria noted that America was the "proving ground for [Du Pont's] beloved theories". In the 1760s and 1770s Du Pont had written that America furnished proof of the Physiocratic doctrine that economic prosperity was the result of encouraging agricultural production, a numerous rural population, free trade and taxes derived from the land. Op. cit., note 23 above, pp. 24-5, 269.

${ }^{25}$ Papers TJ, vol. 12, p. 329. As late as 31 March 1811 Du Pont and Jefferson were still discussing the merits of home-care. E. M. Sowerby, op. cit., note 15 above, vol. 3, p. 34 note.

${ }^{26}$ As late as 16 May 1824 Jefferson described the hospital as "the last resource of poverty ... For it is poverty alone which peoples hospitals ... how many families... would send their husbands, wives or children to a hospital, in sickness? To be attended by nurses hardened by habit against the feelings of pity, to lie in public rooms, harrassed by the cries and sufferings of disease under every form, alarmed by the groans of the dying, exposed as a corpse, to be lectured over by a clinical professor, to be crowded and handled by his students, to hear their case learnedly explained to them, its threatening symptoms developed, and its probable termination foreboded?" Reprinted in R. J. Honeywell, The educational work of Thomas Jefferson, Cambridge, Mass., Harvard University Press, 1931, p. 266.

27 Papers TJ, vol. 11, 1955, p. 42. Paul V. Turner in his Campus. An American planning tradition, Cambridge, Mass., MIT Press, 1984, p. 76, wrote: "It is also likely that Jefferson was interested in the architectural debates in Paris over the plans for the new hospital of the Hôtel-Dieu, which called for a 'pavilion' system of linked structures-rather like his own later plan for the University."

2814 January-14 August 1787; Papers TJ, vol. 11, pp. 42-3, 123, 174, 234-5; vol. 12, p. 32. 


\section{Louis S. Greenbaum}

associate of Buffon. ${ }^{29}$ In addition he had contacts with the physicist, encyclopédiste, and lifelong friend of Benjamin Franklin, Jean-Baptiste Le Roy, a scientist actively engaged in projects of hospital design and ventilation, who claimed authorship of the Academy's pavilion model. ${ }^{30}$ To the extent that Jefferson's ideas furnished support to Du Pont's and Condorcet's position, the American Ambassador can be said to have taken part in the Parisian hospital debate on the eve of the French Revolution.

Much has been written about Jefferson's geometric neo-classicism, the identification of his cubic architecture with the precise and simple forms of antiquity which symbolized reason and order, "proportional relationships to the sympathetic senses" which reinforced "one's intuitive affinity with the visible, physical world and abstractions from nature". 31 While Jefferson's debts to French neo-classical and visionary architecture as well as the château of Marly have been meticulously documented, ${ }^{32}$ he remembered the pavilion design of the Paris hospitals when he came to sketch the buildings of the University of Virginia years later-five symmetrical pavilions on either side of an open lawn, communicating by covered porches, with a dominating building at the central axis ${ }^{33}$ (see figures 1 and 2). Pavilions numbers 1 to 4 and 10 of the University of Virginia appear strikingly similar to Le Roy's design for his hospital pavilions, in the form of a Roman temple (seemingly derivative of the Maison Carrée at Nîmes, but with a pedimented frontispiece of four columns instead of six). ${ }^{34}$ Similarly Jefferson's pantheon library, which was also used for "religious

${ }^{29}$ Cf. Jefferson's conferral of diplomas of membership in the American Philosophical Society, Papers $T J$, vol. 11, pp. 111, 151, 197.

${ }^{30}$ Papers TJ, vol. 10, pp. 410-11, 524-30; vol. 15, pp. 23, 80-2, 136, 413, 467; vol. 18, pp. 18, 68. Cf. Greenbaum, op. cit., note 7 above, pp. 122-40.

${ }^{31}$ Summarized in B. Pickens, 'Mr. Jefferson as a Revolutionary Architect', J. Soc. arch. Hist., 1975, 34: 259.

32 The eye of Thomas Jefferson, ed. W. H. Adams, Washington, National Gallery of Art, 1976, pp. 167-89; F. D. Nichols, 'Jefferson: the making of an architect' in Jefferson and the arts: an extended view, ed. W. $\mathrm{H}$. Adams, Washington, National Gallery of Art, 1976, pp. 159-85; and 'Architecture' in Thomas Jefferson: $a$ reference biography, ed. M. D. Peterson, New York, Scribners, 1986, pp. 215-32 and Thomas Jefferson's architectural drawings, Boston and Charlottesville, The University Press of Virginia, 1961, p. 8. H. C. Rice, Jr., op. cit., note 2 above, p. 109, cites the work of the architectural historian Fiske Kimball, the first to suggest the Marly connection. Jefferson's first building at Monticello, the south outchamber (1769), frequently called the "honeymoon cottage", to which he brought his bride in 1772, was built in the form of a pavilion (Pickens, op. cit., note 31 above, p. 261). In a stimulating essay, 'Thomas Jefferson et l'architecture métaphorique: "le village académique" à l'Université de Virginie' (Revue d'art canadienne. Canadian Art Review, 1976, 3: 2, pp. 8-34), Gérard Le Coat theorizes a rich mix of influences in Jefferson's academic architecture: utilitarian, didactic (socio-political, ethico-social), epistemological, philosophical, and especially Masonic (". . . the comprehensive plan of the village was inspired by that of the lodge" [p. 30]). Following the example of the late eighteenth-century French architects Jefferson is said to have incorporated the classical appeal to the senses: to move, to instruct and to induce admiration and from their "architecture of character and consciousness" to inform, instruct and convince" (pp. 11-12).

${ }^{33}$ Dumas Malone in The sage of Monticello (vol. 6 of Jefferson and his time), Boston, Little, Brown, 1982, p. 258n., has shown that Jefferson was also familiar with the Plymouth Hospital pavilions, the paradigm of the Hospital Committee (see note 9 above).

34 'Précis d'un ouvrage sur les hôpitaux', pp. 585-600 and 2 plates: Elévation Latérale sur la Ligne A. B. Tracée sur le plan général, et vue des bâtimens de service, des salles et de la coupe de l'église, Bibliothèque Nationale, Paris, Imprimés Vp 47; cf. Greenbaum, op. cit., note 7 above, pp. 126-7; P. A. Bruce, History of the University of Virginia, 1819-1919, vol. 2, New York, Macmillan, 1920, p. 183 ff.; W. B. O'Neal, Pictorial history of the University of Virginia, Charlottesville, University of Virginia Press, 1968, pp. 115-18. 
Thomas Jefferson's University of Virginia and the Paris Hospitals



\section{Louis S. Greenbaum}
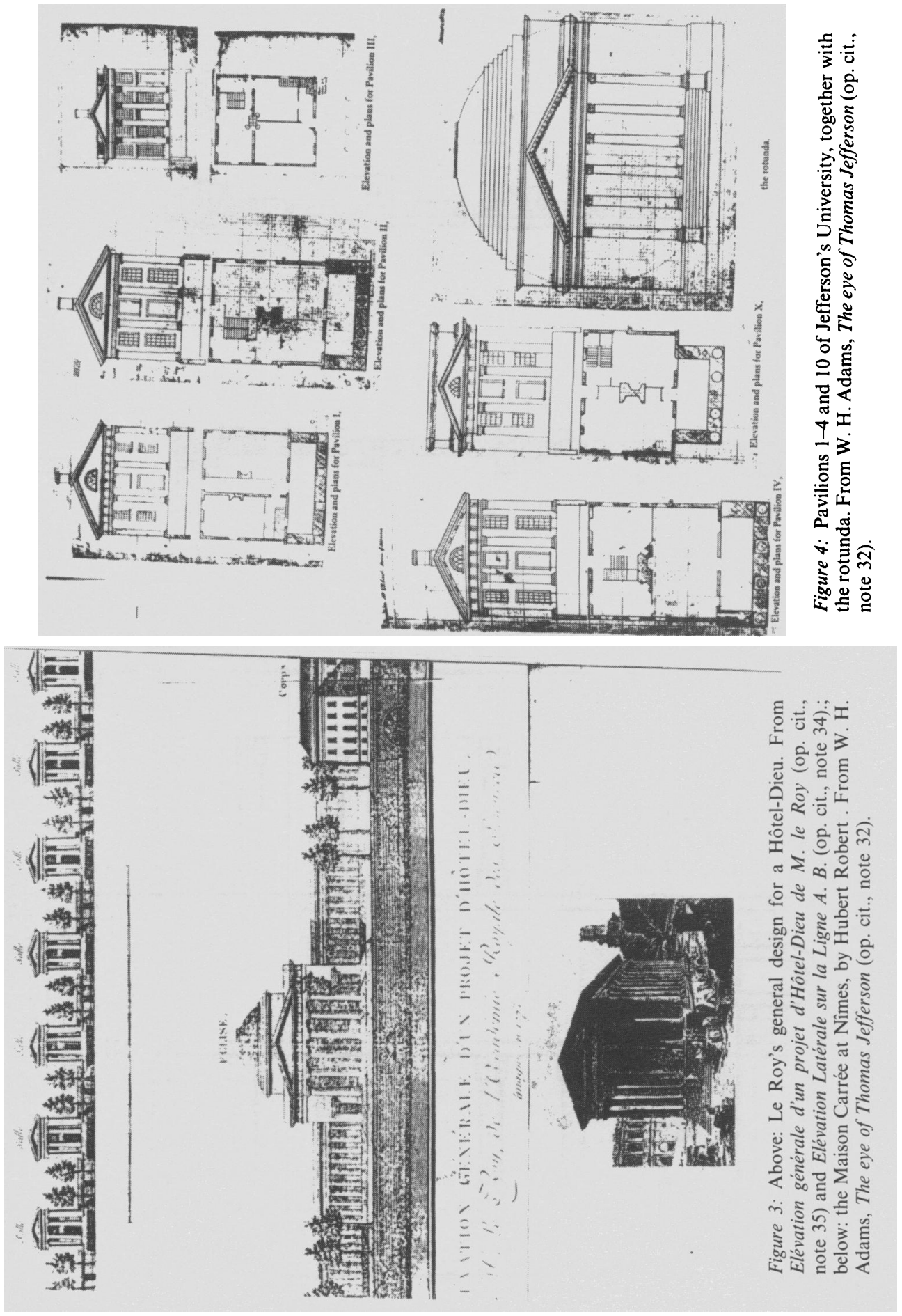


\section{Thomas Jefferson's University of Virginia and the Paris Hospitals}

worship", looks a great deal like Le Roy's domed and columned central chapel flanked by twin rows of hospital pavilions ${ }^{35}$ (see figures 3 and 4).

But why incorporate in the new university designs intended for a hospital? The answer lies in Jefferson's preoccupation with health and medicine, concerns shared with the French scientists a generation earlier. The Roman architecture of the University of Virginia was not only aesthetically pleasing, functional and instructive, but it also comported best with health-promoting objectives. Jefferson's appointment of a medical faculty at the university reflected not merely his lifelong interest in science and medicine but also his conviction that medical studies should be part of general education and that training physicians would enhance the health of citizens.

Jefferson believed that the task of maintaining health rested with each individual. To the author of the Declaration of Independence, good health was the indispensable prerequisite for the enjoyment of life, liberty and the pursuit of happiness. ${ }^{36}$ Jefferson's own long life gave evidence of how the individual needs to pursue good health through regularity in diet, sleep, prudent hygiene and physical exercise. ${ }^{37}$ Countless exhortations to family and friends underscored health as the fundamental natural right, "the first of all objects" central to the advancement of education ("a strong body makes the mind strong"), morality and human improvement. ${ }^{38}$ "You may promise yourself everything - but health, without which there is no happiness. An attention to health then should take place of every other object." 39 In times of illness the sick person should seek recourse to enlightened medicine. Jefferson was inoculated against smallpox in 1766 by the Philadelphia physician William Shippen. ${ }^{40}$ When he dislocated the wrist of his right hand in September 1786, he was visited twenty times by one of the surgical luminaries of Paris, Antoine Louis, permanent secretary of the Royal Academy of Surgery. ${ }^{41}$ When his own daughters

\footnotetext{
${ }^{35}$ Elévation générale d'un projet d'Hôtel-Dieu de M. Le Roy, de l'Académie Royale des Sciences. Imaginé en 1773. Composé pour l'architecture et dessiné en 1780 par Ch. Fr. Viel Architecte de l' Hôpital Générale de Paris; W. B. O'Neal, Jefferson's buildings at the University of Virginia: the rotunda, Charlottesville, University of Virginia Press, 1960, p. 1. Joseph-Jacques Ramée, five years before Jefferson, had designed a campus formed around a rotunda with linked wings at Union College in Schenectady, New York. (R. G. Kennedy, Orders from France. The Americans and the French in a revolutionary world, 1780-1820, Philadelphia, University of Pennsylvania Press, 1990, pp. 9, 225).

${ }^{36}$ One of Jefferson's favourite maxims was "faber suae quisque fortunae." For the compatibility of his ideas and Enlightenment notions regarding the preservation of health as "the first of all goods and the foundation of all other goods of this life" (Descartes), cf. Peter Gay, The Enlightenment: an interpretation, vol. 2, The science of freedom, New York, Norton, 1969, pp. 6-8.

${ }^{37}$ See letter of 21 March 1819 to Dr Vine Utley in The writings of Thomas Jefferson, ed. P. L. Ford, vol. 10, New York, G. P. Putnam's Sons, 1899, pp. 125-7. Cf. A. Blinderman, 'Thomas Jefferson. Administrator, practitioner and patient', $N$. Y. State J. Med., March 1970, pp. 693-4.

${ }^{38}$ The family letters of Thomas Jefferson, eds E. M. Betts and J. A. Bear, Jr., Columbia, University of Missouri Press, 1966, pp. 34-5; Papers TJ, vol. 8, 1953, p. 407; vol. 1, pp. 76-7; vol. 10, p. 308; vol. 12, pp. 17-18; Family letters, p. 407; Ford, Writings of TJ, vol. 12, p. 143 inter alia.

39 Papers TJ, vol. 11, p. 558.

40 D. Malone, Jefferson the Virginian, Boston, Little, Brown, 1948, pp. 99-100.

${ }^{41}$ Massachusetts Historical Society (Boston). MS Account Books, 1783-1790. Memorandum Books or Journal of Expenditures. 31 December 1786. On Louis, cf. P. Huard, Biographies médicales et scientifiques, Paris, Dacosta, 1972, pp. 33-117.
} 
were ill he nursed them. ${ }^{42} \mathrm{He}$ had them inoculated along with his family, slaves, and neighbours at Monticello. ${ }^{43}$

Jefferson's efforts to improve conditions of American public health reach back as far as the Revolutionary War when, as Governor of Virginia, he sought to heal suffering smallpox-infected soldiers. ${ }^{44} \mathrm{He}$ voiced concern to improve sanitation, ventilation, water-supply and disease prevention in Philadelphia, Washington, and the Louisiana Territory. ${ }^{45} \mathrm{He}$ was an active supporter of Jenner's smallpox vaccine and collaborated in Dr Benjamin Waterhouse's project of national vaccination. ${ }^{46}$

As early as January 1805 , Jefferson had hit on an architectural model appropriate for his university. ${ }^{47} \mathrm{He}$ ruled out a single large building (like the Hôtel-Dieu or the College of William and Mary) "always ugly, inconvenient, exposed to accident of fire, and bad cases of infection". Five years later he termed his project design an "academical village"48_referring to the healthiness and moral superiority of the countryside, free from disease and the vices of cities and built in a higher, more salubrious location than the old college at Williamsburg located in the unhealthy lowlands. ${ }^{49}$ Separate "lodges" would house classrooms and professors; "barracks" for students; and covered ways "to give dry communication between all schools". "An academic village instead of a large and common den of noise, filth and fetid air. It would afford the quiet retirement so friendly to study and lessen dangers of fire, infection and tumult." Six years later, in April 1816, he added, "This village form is preferable to a single great building for many reasons, particularly on account of fire, health, economy, peace and quiet."50

Jefferson's plan compares strikingly with the pavilion hospitals of the Paris Academy in the 1780 s, not only by the same symmetrical placement of neo-classical buildings, but also because the French reformers had abandoned the huge hospital monolith for precisely the same motives enumerated by Jefferson a generation later. The scientists had settled on pavilion architecture with its superior fenestration and

\footnotetext{
42 H. Bloch, 'Thomas Jefferson 1743 to 1826 . Thoughts on medicine, child care and welfare', N. Y. State J. Med., (December 15, 1972), pp. 3031-2.

${ }^{43}$ For Jefferson's activities as a vaccinator, cf. W. B. Blanton, Medicine in Virginia in the eighteenth century, Richmond, Garrett \& Massie, 1931, pp. 192-7; E. T. Martin, Thomas Jefferson scientist, New York, H. Schuman, 1952, p. 39; B. S. Leavell, 'Thomas Jefferson and Smallpox Vaccination', Trans. Am. clin. and climatol. Assoc., 1076, 88: 119-27.

44 Blanton, op. cit., note 43 above, pp. $252 \mathrm{ff}$.; H. Gill, The apothecary in colonial Virginia, Williamsburg, Colonial Williamsburg Foundation, 1972, Appendix I, 'Revolutionary hospitals in Williamsburg', pp. 83-91.

${ }^{45}$ The portable Thomas Jefferson, ed. M. D. Peterson, New York, Viking, 1975, pp. 499-500; Jefferson to Dr Benjamin Rush, Ford, Writings of TJ, op. cit., note 37 above, vol. 9, p. 147.

${ }^{46}$ R. A. Halsey, How the President Thomas Jefferson and Dr. Benjamin Waterhouse established vaccination as a public health procedure, History of medicine series ... Library of the New York Academy of Medicine, No. 5, New York, the Author, 1936.

47 January 5, 1805 to Littleton Tazewell, quoted in D. Guinness and J. T. Sadler, Mr. Jefferson architect, New York, Viking, 1973, p. 120. ("In fact a University should not be a house but a village.")

48 To the Trustees for the Lottery of East Tennessee College 6 May 1810, in The complete Jefferson, ed. S. K. Padover, New York, Duell, Sloan \& Pearce, 1943, pp. 1063-4.

${ }^{49}$ TJ to Joseph Priestley, January 19, 1800, Ford, Writings of TJ, op. cit., note 37 above, vol. 9, p. 96. On the connection between health and social environment, education and physical well-being, cf. G. Rosen, 'Political order and human health in Jeffersonian thought', Bull. Hist. Med., 1952, 26: 32-44.

${ }^{50}$ To Governor Nicholas of Virginia, April 2, 1816 in Honeywell, op. cit., note 26 above, p. 78.
} 


\section{Thomas Jefferson's University of Virginia and the Paris Hospitals}

ventilation against "mephytic exhalations" and "morbific miasms" 51 and to isolate contagion and disease - the principal drawbacks of large structures which housed a numerous population. Just as fire in a single building, either hospital or university, would mean the loss of the entire institution - and both the Hôtel-Dieu and William and Mary had sustained costly conflagrations - maladies and epidemics could spread more readily and rapidly in a single building. Relatively small classroom pavilions would re-circulate air in a far more efficient manner and were easier to heat than one large building. Erecting several dining hotels and student dormitories behind the faculty classroom pavilions multiplied the opportunity for isolating disease. Likewise the university community would be protected from sickness-causing elements as they travelled from building to building under covered porches just as the scientists had advocated for improved convalescence and easy communication of all departments. What better health-inducing plan could Jefferson propose for his university than that of a modern, carefully planned hospital?

Jefferson's university would not only attempt to safeguard the health of its students through salubrious site location and architectural design; medical instruction, deemed useful for the education of all students, would also advance public health. If the duty of the state was to protect and ensure the natural rights of man, then the state also had an obligation to provide an educational institution which would further these rights by forming leaders to protect them. One such leader was the physician. While Jefferson praised "surgery seated in the temple of the exact sciences . . . medicine [he believed] scarcely entered its threshold." The founder of the University of Virginia was critical of the contemporary practice of medicine based on fanciful theories, presumption, inexperience and charlatanry. "It is in this part of medicine that I wish to see a reform, an abandonment of hypothesis for sober facts, the first degree of value set on clinical observation and the lowest of visionary theories," a medicine based on "observation and experiment" ${ }^{52}$ Rigorously trained doctors would enhance the health of the citizenry and thereby increase the potential for the enjoyment of natural rights and the strength of the political system. One of the university's six professors would teach anatomy, surgery, history of the progress and theories of medicine, physiology, pathology, materia medica and pharmacy. The University of Virginia provided the first full-time state-supported clinical faculty in a university medical school in the United States. ${ }^{53}$ The comprehensive medical and scientific curriculum planned by Jefferson, the emphasis on preclinical training and clinical instruction under close supervision of the medical school faculty became the norm in

\footnotetext{
${ }^{51}$ On Lavoisier's experiments on oxygen requirements in hospitals and other public buildings, cf. L. S. Greenbaum, 'The humanitarianism of Antoine Laurent Lavoisier', Stud. Voltaire 18th Century, 1972, 88: 654-5, and the incorporation of this work into the recommendations of the Paris Hospital Committee relating oxygen requirements into the design of hospital pavilions. Cf. Greenbaum, op. cit., note 7 above, p. 49.

52 Quoted in S. A. Bedini, Thomas Jefferson. Statesman of Science, New York, Macmillan, 1990, pp. 380-1, 423-4. On Jefferson's views of physicians and contemporary medical practice, cf. S. X. Radbill, 'Thomas Jefferson and the doctors', Trans. Stud. Coll. Physicians Phila., 4 ser., 1969, 37: 106-14; C. R. Hall, 'Jefferson on the medical theory and practice of his day', Bull. Hist. Med., 1957, 31: 235-45.

${ }^{53}$ Bruce, op. cit., note 34 above, vol. 2, p. 106; J. S. Spratt, 'Thomas Jefferson: the scholarly politician and his influence on medicine', Southern med. J., 1976, 69: 365. L. H. Cohn, 'Contributions of Thomas Jefferson to American medicine', Am. J. Surg., 1979, 138: 286-92.
} 


\section{Louis S. Greenbaum}

American medical schools. ${ }^{54}$ It was Jefferson's good fortune to attract the gifted practitioner and scholar Robley Dunglison to assume the clinical chair, a man responsible for training numerous doctors in the young Republic. ${ }^{55} \mathrm{~A}$ second faculty member, John Patton Emmett, Professor of Natural History, gave medical instruction in chemistry, botany and comparative anatomy. ${ }^{56} \mathrm{Dr}$ Thomas Johnston became the first demonstrator in anatomy and surgery. ${ }^{57}$

Jefferson believed fervently in clinical and anatomical studies as the basis of medical education. No expense was spared in this area of university instruction. Before March 1825, Jefferson had designed an "Anatomical Theatre" to perform dissections. Construction was underway before his death a year later and completed in $1827 .{ }^{58} \mathrm{~A}$ letter to Dunglison of 26 November 1825 included the draft of a prosposal for a university dispensary. ${ }^{59}$ Approved by the Board of Visitors on 4 April 1826 , only three months before Jefferson's death, the clinic would provide vital learning experience to physicians in training, including surgery (which, Jefferson had written earlier, was the only branch of the medical art lacking in Virginia ${ }^{60}$ ) "for the purpose of dispensing medical advice, vaccination, and aid in surgical cases of ordinary occurrence to applicants needing them". Those who could afford it would pay a fifty-cents fee; the indigent would receive services free. Not only would medical science be served through the educational function of the dispensary, but the sick poor would receive life-promoting attention. No doubt in Jefferson's mind the dispensary represented an efficient form of assistance, satisfying the moral responsibility of society to provide health services to those in need. Clinical medicine was joined to compassionate care. The poor patient would be treated through the latest advancements of medical science and with humane consideration.

Reason and the moral sense came to form a sympathetic alliance, a merging of "head and heart" which perhaps best characterizes the Jeffersonian position on health-care. Viewed in this light, his University of Virginia was not merely the emblem of freedom and progress through enlightenment but also an instrument for the improvement of the human condition through better health, and with it greater happiness, independence and material prosperity.

Jefferson esteemed the Paris architecture he studied in the 1780s as the standard by which to measure great buildings. He wrote that when the White House and Capitol in Washington were completed "the result will not be more beautiful than the

\footnotetext{
${ }^{54}$ A. de Jarnette Hart, Jr., 'Thomas Jefferson's influence on the foundation of medical instruction at the University of Virginia', Ann. med. Hist., 1938, 10: 56.

${ }^{55}$ S. X. Radbill, 'Dr. Robley Dunglison and Jefferson', Trans. Stud. Coll. Physicians of Phila., 4 ser., 1959, 27: 40-4; The Jefferson-Dunglison letters, ed. J. M. Dorsey, Charlottesville, University of Virginia Press, 1960.

${ }^{56}$ Bruce, op. cit., note 34 above, vol. 2, p. 106.

57 W. B. Bean, 'Mr. Jefferson's influence on American medical education', Virginia med. monthly, 1960, 87: 671; B. S. Leavell, 'Jeffersonian ideals endowed the University of Virginia', Virginia med. monthly, 1977, 104: $91-6$.

${ }^{58}$ O'Neal, op. cit., note 34 above, pp. 34-5.

59 Op. cit., note 55 above, pp. 47-8. The hospital committee of the French Academy of Sciences had also proposed a series of "général dispensary" built in the parishes of Paris to supplement the medical/surgical services of the four major hospitals. Extrait des registres de l'Académie Royale des sciences du 12 mars 1788 , op. cit., note 5 above, p. 12.

60 Peden (ed.), op. cit., note 20 above, p. 134.
} 
Thomas Jefferson's University of Virginia and the Paris Hospitals

pavilions at the new gates of Paris". ${ }^{61}$ When Daniel Webster visited the Sage of Monticello in December 1824 the whole conversation was French society, politics and literature as Jefferson knew it in the 1780s intermingled with the University of Virginia. ${ }^{62}$ In passing judgment on Jefferson's personality, Henry Adams concluded that "with all his extraordinary versatility of character and opinions, he seemed during his entire life to breathe with perfect satisfaction nowhere except in the liberal, literary and scientific air of Paris in 1789.",63

${ }^{61}$ Quoted in R. G. Kennedy, op. cit., note 35 above, p. 438. Cf. A. Vidler, Claude-Nicholas Ledoux: architecture and social reform at the end of the Ancien Régime, Cambridge, Mass., MIT Press, 1990, pp. 209-35.

${ }^{62}$ Rice, op. cit., note 2 above, p. 125.

63 Ibid. 